\title{
土木学会規準：「コンクリート用練混ぜ水の品質規格（案） -JSCE-B101-1995」について
}

\author{
JSCE STANDARD “QUALITIES OF WATER FOR CONCRETE”
}

コンクリート委員会・規準関連小委員会

Committee on Concrete Specifications and Recommendations, Committee on Concrete

\section{（1）まえがき}

この品質規格 (案) は, 土木学会コンクリート委員会 規準関連小委員会において 1988 年に審議が開始された ものであり，1989 年の JIS A 5308 (レディーミクストコ ンクリート）の改正の際に, 練混ぜ水の品質が附属書 9 として具体的に規定されたことに伴って, 練混ぜ水の品 質を検討することの重要性が議論された. 特に, セメン トからの溶出成分および各種混和剤等を含む回収水の品 質の検討, 水の品質試験項目とその規格値が検討された. そしてモルタルの圧縮強度試験, セメントおよびモルタ ルの凝結試験, 回収水の調查などが実施された ${ }^{1) ~ 3)}$. これ らの検討の結果, 現状の回収水の品質の実態とこれを用 いたコンクリートの長期強度および耐久性等について不 明の事項が多いことから, 本品質規格（案）は回収水を 適用範用から除くこととし，これ以外のコンクリート用 練混ぜ水についてその品質を定めたものである.

\section{（2）水道水以外の水の品質基準の概要}

本規準における水の品質は, 上水道水および上水道水 以外の水の 2 つに分けて規定している. しかし, 回収水 は, JIS A 5308-1989 附属書 9 （レディーミクストコン クリートの練混ぜに用いる水) においては, その品質基 準を定めているが，本品質規準（案）においては規定し ていない. 土木学会規準と JIS A 5308 附属書 9 に規定さ れている回収水を除く上水道水以外の水の品質基準は表 - 1 に示すとおりである.

土木学会規準の水の品質基準は, 懸濁物質の量, 溶解 性蒸発残留物の量, 塩化物イオン量, 水素イオン濃度 $(\mathrm{pH})$, モルタルの圧縮強度比および空気量の増分の 6 項 目で, JIS A 5308 の附属書 9 と異なる部分がある. 懸濁 物質の量, 溶解性蒸発残留物の量および塩化物イオン量 は, 両規格の品質規定值が同じである. その他の項目に ついては, 以下に解説する。
表一 1 コンクリート用練混ぜ水の品質基準 一上水道水以外の水 (回収水を除く) 一

\begin{tabular}{|c|c|c|}
\hline & 土木学会規準 & JIS A 5308 \\
\hline 項 & 品 & 品 \\
\hline 䜿 濁 物 質 $の$ 量 & $2 \mathrm{~g} / \ell$ 以下 & $2 \mathrm{~g} / \ell$ 以下 \\
\hline 溶解性蒸発残留物の量 & $1 \mathrm{~g} / \ell$ 以下 & $1 \mathrm{~g} / \mathrm{\&}$ 以下 \\
\hline 塩化物イオン $\left(\mathrm{CI}^{-}\right)$量 & 200ppm以下 & 200ppm以下 \\
\hline 水素イオン浿度 $(\mathrm{p} \mathrm{H})$ & $5.8 \sim 8.6$ & $\ldots \ldots \ldots \ldots \ldots \ldots$ \\
\hline セメントの凝結時間の差 & & $\begin{array}{l}\text { 始発は30分以内 } \\
\text { 終結は60分以内 }\end{array}$ \\
\hline モルタルの压縮強度比 & $\begin{array}{l}\text { 材齢 1日,7日およ } \\
\text { び28日で90\%以上 }\end{array}$ & $\begin{array}{l}\text { 材齡 7日, 28日 } \\
\text { で90\%以上 }\end{array}$ \\
\hline 空 気 量 の 增 分 & $\pm 1 \%$ & .................... \\
\hline
\end{tabular}

\section{（3）水素イオン濃度（pH）}

水素イオン濃度は, 原因物質の種類に関係なく, その 值が高低いずれに片寄っても，コンクリートの耐久性に 悪い影響を及ぼすことが懸念されることから，その範囲 を規定している. 水素イオン濃度の許容範囲は, 上水道 水の規定值を参考にしたもので，上水道水を練混ぜ水と したときのコンクリートの品質には, 特に問題が認めら れないことを根拠にして定めている。

（4）セメントの凝結時間の差とモルタルの圧縮強度比 JIS A 5308 附属書 9 では, セメントの凝結時間の差と 材歯 7 日および 28 日におけるモルタルの圧縮強度比を, 水の品質項目に規定している. セメントの凝結時間の差 は, セメントの正常な水和が練混ぜ水の有害物質によっ て阻害または促進される程度を判定するために規定され ている、しかしながら, 本品質規格（案）ではこの品質 項目を廃止し, モルタルの材齢 7 日および 28 日の圧縮強 度比に加え, 材齢 1 日における圧縮強度比を規定してい る.

セメントの凝結時間の差を廃止, 材齢 1 日における圧 縮強度比を採用した理由は, 図一 1 , 図一 2 および図一 3 


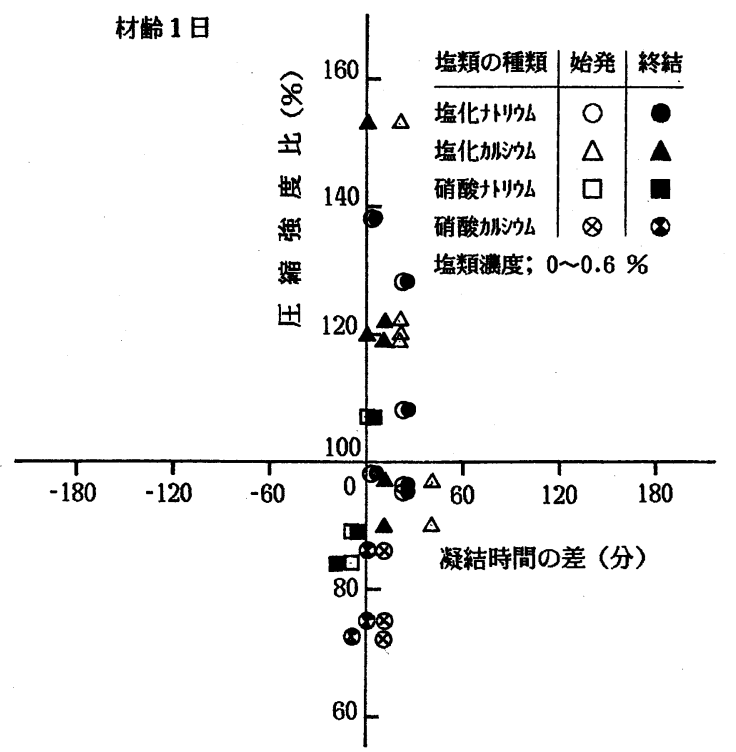

図一 1 モルタルの材齢 1 日圧縮強度比とセメントの凝結時 間の差の関係

に示すモルタルの材齢 1 日圧縮強度比とセメントあるい はモルタルの凝結時間の差との関係の実験結果を根拠に している2)

図一 1 より, 材齢 1 日の圧縮強度比は, 練混ぜ水の塩 類の種類および濃度によって広く分布するが，セメント の凝結時間の差は, それらに関係なく, 始発で \pm 30 分以 内, 終結で \pm 60 分以内と非常に狭い範囲に分布してい る.これに対し，図一 2 および図一 3 より，モルタルの 凝結時間の差は, 塩類の種類および濃度によって, 始発 で \pm 30 分以上, 終結で \pm 60 分以上に広く分布し, 材齢 1 日の圧縮強度比とほほ対応する傾向が認められる。特に, この傾向は高濃度の塩類を含む水で練り混ぜた場合に顕 著である。

このようにセメントの凝結時間の差は, 練混ぜ水の有 害物質量がセメントの水和の程度に及ぼす影響を必ずし も反映していないのに対して, モルタルの凝結時間の差 は,この試験がモルタルの貫入抵抗を測定しているため, セメントの水和の程度をよく反映している.したがって, 練混ぜ水の促進性物質および遅延性物質の有無の判定に は，モルタルの貫入試験による凝結時間の差拉よび材齢 1 日のモルタルの圧縮強度比が有効である. しかし, モ ルタルの貫入試験による凝結試験は, 試験者の拘束時間 が長くなるなどの問題点があるため, 本品質規格（案） では, 材齢 1 日のモルタルの圧縮強度試験を採用したの である。

\section{（5）モルタルの圧縮強度比の試験材齢と許容值}

モルタルの圧縮強度比は, 練混ぜ水の品質がセメント

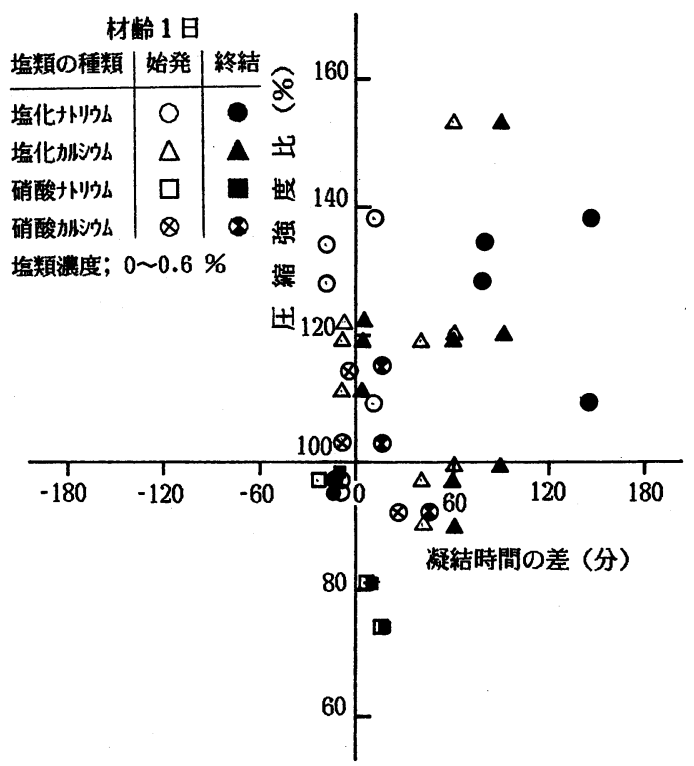

図一2 モルタルの材齢 1 日圧縮強度比と凝結時間の差の関 係

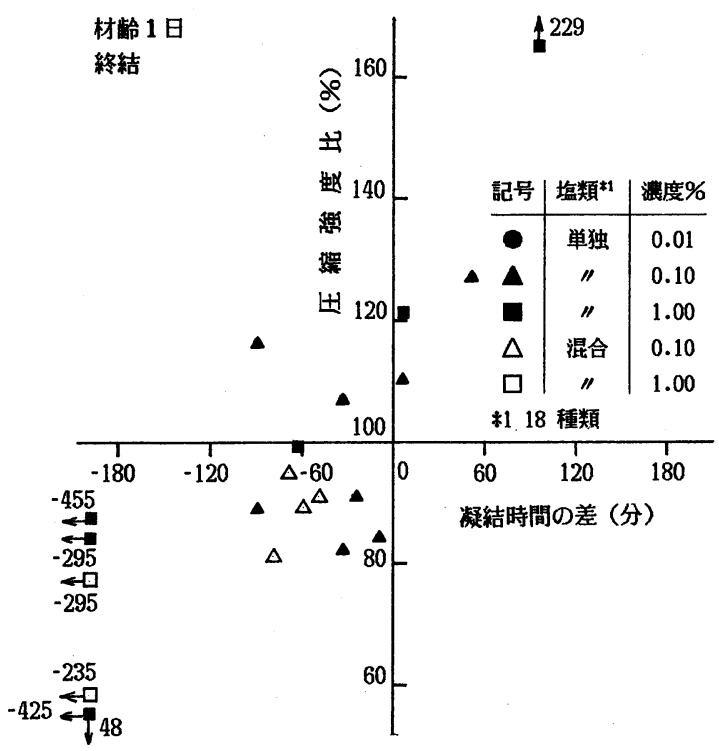

図一3 モルタルの材齢 1 日圧縮強度比と凝結時間の差の関 係

の強度発現に及ぼす影響を直接判断できる指標であるこ とから規定したものである. JIS A 5308 附属書 9 では, 圧縮強度比として,材齢 7 日および 28 日における下限值 だけを規定している.本規準でも，図一4に示す $\mathrm{pH} 5.8 \sim 8.6$ の塩類を含む水を用いたモルタルの圧縮強 度比と材齢との関係の実験結果に基づいて，90\%の下限 值を規定している．すなわち，图一 4 より，材齢 1 日の 圧縮強度比は, 練混ぜ水に促進性物質が含まれる場合, 


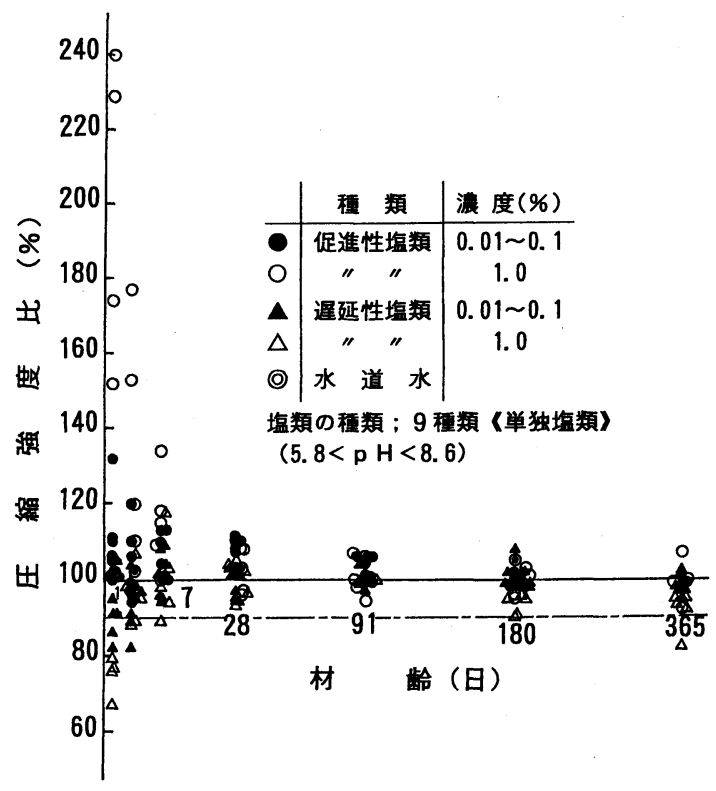

図一 4 モルタルの圧縮強度比と材齢の関係 (練混ぜ水の $\mathrm{pH} ； 5.8 ８ .6$ )

高濃度で 110〜240\%, 遅延性物質が含まれる場合, 高濃 度で 65〜80\%, 低濃度でも 80〜 100\%と，それぞれ広く 分布している. 強度比の範囲は, 材齢の進行とともに狭 まり, 材齢 7 日で 90〜 130\%, 材歯 365 日で 90〜 110\%と, 材歯令の経過とともに基準水の強度（強度比 $100 \%$ ）に近付 く傾向がみうけられる.なお，材歯 1 日の圧縮強度比が 大きな值を示した場合においても, 練混ぜ水の $\mathrm{pH}$ が 5.8〜8.6 の範囲であれば, 強度比は, 有害物質の種類お よび濃度に関係なく，365日の長期材齢においても $90 \%$ 以下になることはないようである。

また, 材齢 1 日における圧縮強度比は, セメント, 細 骨材および試験者の熟練度などが異なった場合において も, 有害物質の各濃度ごとの試験值のバラツキが小さく, 練混ぜ水の品質の適否判定が可能であることも報告され ている1).

\section{（6）空気量の増分}

練混ぜ水に洗凧, 油脂, フミン酸などが混入している 場合, モルタルの空気量が増加する。この悪影響はモル タルの圧縮強度比にも反映されるが, 空気量の測定に よって洗剤等の混入の有無を容易に判定できることか ら, 本品質規格（案）では空気量の増分を練混ぜ水の品 質項目に追加して, $\pm 1 \%$ と規定した。

\section{（7）まとめ}

今回制定された土木学会規準（コンクリート用練混ぜ 水の品質規格 (案) JSCE-B101-1995）の内容を，制定の 背景と理由とともに概説した。本品質規格（案）では， 上水道水と回収水を除く上水道水以外の水を対象とし, 回収水の品質規格については今後の課題となった．本規 準は, 土木学会コンクリート委員会規準関連小委員会の 歴代の委員長はじめ委員各位の活発な活動によって制定 することができたことを記し，厚くお礼申し上げます。

\section{参考文献}

1) 土木学会：コンクリート標準示方書（平成 3 年版）改訂 資料およびコンクリート技術の今後の動向, 土木学会規 準の改訂と「コンクリート標準示方書 (規準編)」につい て, コンクリートライブラリー70, pp.28-43, 1991.9.

2）松村, 黒井：塩類を含む水を用いたモルタルの凝結・強 度特性, 土木学会第 21 回関東支部技術研究発表会講演概 要集, pp.478-479, 1994.

3）松村, 黒井：塩類を含む水で練り混ぜたモルタルの凝結 と強度, 土木学会第 22 回関東支部技術研究発表会講演概 要集, pp.466-467, 1995.

4）仕入, 児玉: コンクリート練り混ぜ水の水質の規準化に 関する実験的研究一その 1 -水中の不純物が㠜結・強度・ 収縮に及ぼす影響一, 日本建築学会論文報告集, No. 162, 1969.6 .

5）仕入：コンクリートの性質におよぼす練り混ぜ水の水質 の影響，セメント・コンクリート, No. 310, 1972.

（文責 : 黒井登起雄, 國府勝郎, 辻 幸和)

(1995.10.9 受付)

\section{規準関連小委員会}

辻 幸和 (委員長), ○魚本健人, ○梅原秀哲, 大賀宏行, 大即信明, 小澤一雅, 河野広隆, 木曾 茂, 栗田守朗, 黒井 登起雄, 國府勝郎, ○坂井悦郎, 高田 誠, 富田六郎, 原田修輔, 福手 勤, 丸山武彦, 宮川豊章, 宮本文穂, 宮本征夫, ○睦好宏史, 本橋賢一, 山崎耐之, 山本孝一, ○六郷恵哲 